\title{
Musical Journeys in the Malay World
}

\author{
Dick van der Meij \\ Syarif Hidayatullah State Islamic University, Jakarta \\ dickvandermeij2012@gmail.com
}

Margaret Kartomi, Musical Journeys in Sumatra. Urbana, Chicago and Springfield: University of Illinois Press 2012, xxix +478 pp. ISBN 9780252036712

Bart Barendregt (ed.), Sonic Modernities in the Malay World. A History of Popular Music, Social Distribution and Novel Lifestyles (1930s-20oos). Leiden: Brill 2014 (VKI 290), xi + 375 pp. ISSN. 1572-1892; ISBN 9789004259867.

Barbara Hatley (ed.), with Brett Hough. Performing Contemporaty Indonesia. Celebrating Identity, Constructing Community. Leiden: Brill 2015 (VKI 297), xv + 265pp. ISSN 1572-1892; ISBN 9789004282414.

Margaret Kartomi's book is the first introduction on the musical traditions of Sumatra and covers musical arts as well as performing arts that contain music. The musical traditions of other parts of Indonesia including those of Java, Bali, and Madura have been well documented and form the subject of many books and articles. With the publication of this book, an overview of the music of Sumatra has finally seen the light. Sumatra is the sixth largest island in the world and it is impossible to cover the island's entire musical traditions in a single volume because there are simply too many. The book limits itself therefore to the traditions of Aceh, North Sumatra, Riau, West Sumatra, South Sumatra, and Bangka-Belitung. It may be said that the island has thus geographically been covered quite nicely. The book consists of four parts: I. West Sumatra and Riau; II. South Sumatra and Bangka; III. North Sumatra; and IV. Aceh. The chapters form essays in their own rights and the readers may thus opt to read each of them separately, although reading it straight through provides a valuable overview of the traditions it covers.

Music in this book includes vocal, instrumental, and body percussion, as well as dance and other bodily movements and other theatrical performances in a range of settings including modern, traditional, and ceremonial, as well as novel media-covered artistic tours and missions for and during government

(C) DICK VAN DER MEIJ, 2016 | DOI: 10.1163/22134379-17202019

This is an open access article distributed under the terms of the Creative Commons Attribution-Noncommercial 3.0 Unported (CC-BY-NC 3.0) License. 
and commercial gatherings. The book is also a highly personal account of the many performers and traditions Kartomi encountered on the island during her many stays in Sumatra from 1971 to 2011. It is a mixture of social science and ethnomusicology and is illustrated, and well written. Musical scores and drawings of instruments and photographs of performances and performance settings enliven the book. Because of its open and personal style it offers an accessible place to start for any student engaged in the musical traditions of Southeast Asia.

Over the last couple of decades many musical traditions have disappeared in Sumatra due to religious, governmental, and commercial pressures (p. xxvi). Through her book, Kartomi has ensured that many traditions have been described and thus have been opened up to the world, easily fulfilling its ambition to 'help future observers and scholars who might join me in researching this virtual musical terra incognita' (p. xxvi). The book does not deal with popular music as it needs and deserves detailed coverage in its own right. In view of the oral/aural component indispensable in music and theatrical performances it is a pity that no $\mathrm{CD}$ has been added to the book.

The book links up nicely with the other two volumes briefly discussed here as the 'major themes that recur throughout the chapters ([which] include) identity, rituals and ceremonies, religion, the impact of foreign contact on the performing arts, the musical instruments and pitch variability, the dances and music-dance relationships, social class, gender issues, and arts education' (p. 6).

The second volume edited by Barty Barendregt contains contributions by Bart Barendregt himself, Philip Yampolsky, Jan van der Putten, Adil Johan, Andrew Weintraub, Emma Baulch, Lars Gjelstad, Bettina David, Jeremy Wallah, Kees van Dijk, Wim van Zanten and Tan Sooi Beng.

The previous book discusses many traditions that have already disappeared or are in the process of being lost or are evolving almost beyond recognition. Some ideas of these changes may be gleaned from the present book which, of course, cannot adequately address all the 'sonic modernities' in the entire Malay world. Nevertheless, its authors give us a sense of what these modernities entail. Its subjects include Dutch East Indies radio (Yampolski), Malay ronggeng (Van der Putten), policing Malaysian and Singaporean popular music culture (Adil Johan), Melayu popular music in Indonesia (Weintraub and Baulch), popular music and youth cultures in Solo, Central Java (Gjelstad), dangdut (David and Wallach), singing and politicians (Van Dijk), music in Sunda, West Java, and modernising songs of the forest (Tan Sooi Beng). The book is a compilation of papers from a workshop and a presentation to launch the research program 'Articulation of Modernity' which aims to analyse the 'interplay between the production of popular music, shifting ideas of the modern, 
and processes of social differentiation in twentieth-century Southeast Asia' (p. 1).

The book is a good illustration of what has become the main tenet of our research programme: rewriting Southeast Asia's twentieth century from the perspective of popular music makers, the entertainment industry and its ever changing audiences'. With this aim in mind, the book presents a whole different notion of music making than the first book and gives us a good idea how notions of culture and society change ever more quickly in our globalised world.

Scholars of other disciplines in the social sciences may take to heart Barendregt's remark on page 5 that the compartmentalisation of time in such things as 'late colonial period', 'Japanese occupation', the 'Revolution', 'Independence', and especially that of 'New Order Era' and 'Reformasi' obscures complex processes of continuity and change. Indeed, politics and war change much but not everything.

The third book explored the format and meanings of performance — theatre, along with music, dance, and video arts—created and staged in Indonesia today.' (p. 1). It looks more at the political role of performance both in affirming and in contesting political constellations and it sees theatre and other expressions of stage performance from the role they play in the creation and maintenance of notions of community. The book is introduced by Barbara Hatley and takes the reader geographically from Central Java (Barbara Hatley; Yoshi Fajar Kresno Murti; Alexandra Crosby) to East Java (Rachmah Ida), Bali (Brett Hough), West Java (Neneng Lahpan and Wawan Sofwan), and Aceh (Reza Idria). Indonesian performances outside Indonesia cover Australia (Aline Scott-Maxwell) and the Netherlands (Fridus Steijlen). Audiences are the focus for Jakarta (Alia Swastika) while Edwin Jurriëns sheds light on video art communities in Indonesia. The book ends in notes from a 2009 symposium on a performance by Ugaran Prasad and Concluding Comments are by Ariel Heryanto, Chua Beng Huat, and Denise Varney.

After the start of the Reformation era after the demise of the New Order regime, Indonesian performances have been given much more freedom of expression than ever before. This is reflected in the many changes that take place in performance practices and contents. The papers in the book address 'community level performances, new cultural spaces and forms, popular music, visual media, developments in Indonesian performances in different regions and in two key diasporic sites, Australia and the Netherlands'.

The three books expertly show from a wide range of examples how musical and theatrical performance traditions evolve with social changes and (in)stabilities. Each in their own temporal and cultural contexts, performances reveal 
and create feelings of community belonging and identity while they adapt to changing circumstances, be they cultural, political, or religious. The first book shows how rapid these changes take place and reveals how fluid these traditions really are. The other books show that no matter what, new traditions that appear build on old ones and thus demonstrate that, ultimately, when music and theatrical performances do not change this may be seen as a sign of stagnation. Change is the element that is most dynamic and defining in these performance traditions, not the stifling urge to maintain and preserve. The more vibrant the changes in cultural and political circumstances, the more direct and pertinent musical and performance changes become. In view of the rapid changes Indonesia is going through in the decentralisation era, we may be sure that more changes in music, performance, and theatre are to be expected. Hopefully they will be closely observed and studied. 